\title{
Effects of Rainfall and Fertilization on the Yield of a Winter Rye (Secale cereale L.) Monoculture in a Long-Term Experiment
}

\author{
L. MÁRTON \\ Research Institute for Soil Science and Agricultural Chemistry (RISSAC) \\ of the Hungarian Academy of Sciences, Budapest
}

\section{Introduction}

Climate change is recognized as a serious environmental issue (JOHNSTON, 2000). It has repeatedly affected much or all of the Earth (LÁNG, 2005). Available evidence suggests that such changes are not only possible, but likely in the future, potentially with large impacts on ecosystems and societies (BARROW et al., 2000; NRC, 2002; RAJENDRA, 2004; MÁRTON, 2004, 2005a,b). During the $20^{\text {th }}$ century the atmosphere greenhouse gases, especially $\mathrm{CO}_{2}$, increased markedly (SzÁsz, 2005). Nearly concurrently with this, relative global temperatures of the $19^{\text {th }}$ century increased by $0.6^{\circ} \mathrm{C}$ (LÁNG et al., 2004; JOLÁNKAI, 2005; VÁRALLYAY, 2005).

In the coming decades global plant production faces the prospect of a changing climate and environment, as well as the known challenge of feeding the world's population, predicted to double the present six billion by about the year 2050 . The prospective climate change is global warming with associated changes in hydrological regimes and other climatic variables induced by the increasing concentration of radiatively active greenhouse gases. Climate change could have far-reaching effects on patterns of trade among nations, development, and food security. These changes (largely caused by human activities) are likely to affect crop yields differently from region to region across the globe (MÁRTON, 2005a,b; SETH \& JEFFREY, 2005). A significant issue that becomes apparent from even a cursory summary of existing knowledge is that from the crop's perspective the important point is the net effect of all the environmental changes that occur, or might occur, at any given place and time.

At present, plenty of agricultural investigations focus on understanding the relation between mean climate change and crop production (VÁrALlYAY, 1992). Few investigations, however, have studied the effects of climate variability on agricultural crop yields (NÉMETH, 2004). The response of agricultural crop yields to changes in climate variability have been attributed primarily to changes in the frequency of extreme climatic events (EU, 2003). Recent studies demonstrated the greater effect of the frequency of extreme climatic events than changes in the mean

Correspondence to: LÁSZLÓ MÁRTON, Research Institute for Soil Science and Agricultural Chemistry of the Hungarian Academy of Sciences, H-1022 Budapest, Herman Ottó út 15. Hungary. E-mail: marton@rissac.hu 
climatic response (EM, 2004). Hence, in studying the effects of climatic change on crop production, the changes in the climatic variability and associated weather patterns should be included (BARROW et al., 2000).

Changes in weather patterns were observed throughout Europe (including Hungary) as early as 1850 . Among the natural consequences of changing weather patterns, years of drought (rainfall deficit) and wet (rainfall excess) conditions, resulted in problems among plant nutrition and field crop production (EU, 2003). Whereas rye (Secale cereale L.) is a crop of worldwide importance, limited research has been carried out on the effects of climate change on these crops (KÁDÁR et al., 1984; MÁRTON, 2002, 2003). These crops react sensitively to the prevailing weather conditions (such as rainfall) and, for this reason, understanding the effects of anthropogenic climate change on its production bears great importance. In addition to rainfall, crops require an optimal level of soil macronutrients: nitrogen, phosphorus and potassium (KÁDÁR, 1992; KÁDÁR et al., 1984).

Most environmental research focus on only one, or very few changes instead of the concomitant multiple changes occurring in our world. Unfortunately, however, the bulk of past research has focused on one factor at a time. As a result for example, much is known about the effects of a change in a geochemical element (macro, meso, micro or trace) loading on yield of some crops, but much less information is available about the effects of a change in a geochemical element in combination with a change in rainfall quantity and distribution on the yield of those same crops. It is obviously the effects of all the environmental changes occurring, rather than just a geochemical element (or just other geochemical elements, or just rainfall quantity and distribution etc.), that is of importance to any crop. Although much of this paper focuses on single factors (rainfall quantity, rainfall distribution, N, P, K fertilization), it was our intent to emphasize that the net effect of multiple environmental changes on rye is far more important than the effect of a single factor on that crop.

So, findings are presented on interactions related to rainfall quantity, rainfall distribution changes and N, P, K fertilization effects on the yield of rye grown on a calcareous sandy soil with a low humus content in an ecologically fragile experimental site at Örbottyán in Hungary from 1961 to 2004 for 44 years.

\section{Materials and Methods}

The effect of rainfall (quantity and distribution) on crop fertilization factors, such as macronutrients and yield, were studied during a long-term (1961 to 2004) field experiment on a calcareous sandy soil with low humus content in North Hungary at the Örbottyán Experimental Station of RISSAC. In 1959, at the time the experiment was set up (LÁNG, 1973) the ploughed layer of the experimental soil could be characterized as follows: $\mathrm{pH}\left(\mathrm{H}_{2} \mathrm{O}\right): 7.5-7.8, \mathrm{pH}(\mathrm{KCl})$ 6.9-7.1, humus content: $0.6-1.0 \%$, clay content: $\sim 5 \%, \mathrm{CaCO}_{3}$ content: $3-7 \%$, $\mathrm{AL}$ (ammonium lactate) soluble $\mathrm{P}_{2} \mathrm{O}_{5}$ and $\mathrm{K}_{2} \mathrm{O}$ content: $40-60$ and $50-100 \mathrm{mg} \cdot \mathrm{kg}^{-1}$. The experiment in- 
Table 1

Values of the crop-specific drought index (CDI) for rye grown in monoculture during various periods of the experimental years (1961-2004)

(Long-term fertilization experiment, calcareous sandy soil, Örbottyán)

\begin{tabular}{|c|c|c|c|c|c|c|}
\hline \multirow[b]{2}{*}{ Year } & \multicolumn{6}{|c|}{ Period } \\
\hline & $\begin{array}{l}\text { Winter } \\
\text { half year }\end{array}$ & $\begin{array}{l}\text { Summer } \\
\text { half year }\end{array}$ & $\begin{array}{l}\text { Month } \\
\text { (Oct.- } \\
\text { Sept.) }\end{array}$ & $\begin{array}{l}\text { Month prior } \\
\text { to sowing } \\
\text { (Aug.) }\end{array}$ & $\begin{array}{c}\text { Vegetation } \\
\text { period } \\
\text { (Sept.-Jul.) }\end{array}$ & $\begin{array}{c}\text { Harvesting } \\
\text { month } \\
\text { (July) }\end{array}$ \\
\hline \multicolumn{7}{|c|}{ Average years } \\
\hline 1969 & -9 & -3 & 1 & -3 & 1 & 1 \\
\hline 1976 & -1 & 2 & 1 & -5 & 1 & 7 \\
\hline 1978 & -9 & 6 & 1 & -6 & 1 & 6 \\
\hline 1979 & -9 & -9 & 1 & -3 & 1 & -4 \\
\hline 1980 & 9 & -9 & 1 & -5 & 1 & -2 \\
\hline 1981 & 9 & -9 & 1 & 1 & 1 & -4 \\
\hline 1982 & 4 & -9 & 1 & -4 & -1 & 1 \\
\hline 1985 & -8 & 9 & 1 & 5 & -1 & -5 \\
\hline 1987 & -1 & 2 & 1 & 1 & -1 & -6 \\
\hline 1989 & -9 & 9 & -1 & 1 & -1 & -3 \\
\hline 1994 & -9 & -3 & 1 & 3 & 1 & -8 \\
\hline 2001 & -9 & 9 & 1 & -7 & 2 & 9 \\
\hline Mean & -3.5 & -0.4 & 0.9 & -1.8 & 0.4 & -0.7 \\
\hline \multicolumn{7}{|c|}{ Dry years } \\
\hline 1961 & -9 & -4 & -1 & -9 & -1 & 1 \\
\hline 1962 & 9 & -9 & -1 & -9 & -1 & -2 \\
\hline 1964 & -9 & -2 & -1 & 1 & -2 & -1 \\
\hline 1967 & -1 & -9 & -1 & -9 & -1 & -7 \\
\hline 1971 & -9 & -6 & -1 & -4 & -2 & 1 \\
\hline 1984 & -9 & -7 & -1 & 2 & -3 & -9 \\
\hline 1995 & -9 & 1 & -1 & 6 & -2 & -3 \\
\hline Mean & -5.3 & -5.1 & -1.0 & -3.1 & -1.7 & -2.9 \\
\hline \multicolumn{7}{|c|}{ Droughty years } \\
\hline 1968 & -9 & 3 & -1 & 9 & -4 & -2 \\
\hline 1973 & -9 & -4 & -1 & -7 & -3 & -3 \\
\hline 1974 & -9 & -9 & -1 & 2 & -5 & -6 \\
\hline 1983 & 1 & -9 & -1 & -7 & -2 & -7 \\
\hline 1986 & -3 & -9 & -1 & -5 & -4 & -8 \\
\hline 1988 & -7 & -9 & -1 & -2 & -4 & -8 \\
\hline 1990 & -9 & -9 & -1 & -7 & -5 & -6 \\
\hline 1992 & -9 & -9 & -1 & -9 & -4 & -4 \\
\hline 1993 & -9 & -9 & -1 & -9 & -5 & 4 \\
\hline 1996 & -9 & -9 & -1 & -6 & -2 & -5 \\
\hline 1997 & -9 & -9 & -1 & -9 & -3 & -3 \\
\hline 1998 & -9 & 3 & -1 & -7 & -2 & 1 \\
\hline 2000 & -9 & -9 & -1 & -9 & -4 & 3 \\
\hline 2002 & -9 & 5 & -1 & 9 & -4 & -2 \\
\hline
\end{tabular}


Table 1 cont.

\begin{tabular}{|c|c|c|c|c|c|c|}
\hline \multirow[b]{2}{*}{ Year } & \multicolumn{6}{|c|}{ Period } \\
\hline & $\begin{array}{l}\text { Winter } \\
\text { half year }\end{array}$ & $\begin{array}{l}\text { Summer } \\
\text { half year }\end{array}$ & $\begin{array}{l}\text { Month } \\
\text { (Oct.- } \\
\text { Sept.) } \\
\end{array}$ & $\begin{array}{l}\text { Month prior } \\
\text { to sowing } \\
\text { (Aug.) }\end{array}$ & $\begin{array}{l}\text { Vegetation } \\
\text { period } \\
\text { (Sept.-Jul.) }\end{array}$ & $\begin{array}{c}\text { Harvesting } \\
\text { month } \\
\text { (July) }\end{array}$ \\
\hline 2003 & -9 & -9 & -1 & -8 & -4 & -1 \\
\hline 2004 & 9 & -9 & -1 & 3 & -5 & -5 \\
\hline Mean & -6.8 & -6.3 & -1.0 & -3.9 & -3.8 & -3.3 \\
\hline 1991 & -9 & 9 & $\begin{array}{c}\text { Wet ye } \\
1\end{array}$ & -1 & 2 & 9 \\
\hline \multicolumn{7}{|c|}{ Very wet years } \\
\hline 1965 & 9 & 9 & 1 & 9 & 5 & 9 \\
\hline 1966 & 9 & 9 & 1 & 9 & 5 & 9 \\
\hline 1972 & -9 & 9 & 1 & 9 & 2 & 9 \\
\hline 1975 & 4 & -9 & 1 & -1 & 4 & 9 \\
\hline 1977 & 9 & 9 & 1 & 7 & 8 & 2 \\
\hline 1999 & -9 & 9 & 1 & 8 & 3 & 9 \\
\hline Mean & 2.2 & 6.0 & 1.0 & 6.8 & 4.5 & 7.8 \\
\hline $\begin{array}{l}\text { Grand } \\
\text { mean }\end{array}$ & -4.5 & 0.6 & 0.2 & -0.6 & 0.3 & 2.0 \\
\hline
\end{tabular}

Remarks: Average years: Equivalent to the 30-year (1961-1990) rainfall mean at Örbottyán Experimental Station; dry year: $-10--20 \%$; droughty year: above $-20 \%$; wet year: $+10-$ $+20 \%$; very wet year: above $+20 \%$

cluded ten treatments in five replications, giving a total of 50 plots $\left(35 \mathrm{~m}^{2}\right.$ each) arranged in a Latin square design.

From the $1^{\text {st }}$ to the $25^{\text {th }}$ year the fertilization rates (per hectare per year) were: 0 , 50 and $100 \mathrm{~kg} \mathrm{~N} ; 0$ and $54 \mathrm{~kg} \mathrm{P}_{2} \mathrm{O}_{5} ; 0$ and $80 \mathrm{~kg} \mathrm{~K}_{2} \mathrm{O}$ and their combinations. From the $26^{\text {th }}$ year on these rates (per hectare per year) were 0 and $120 \mathrm{~kg} \mathrm{~N} ; 0,60$ and $120 \mathrm{~kg} \mathrm{P}_{2} \mathrm{O}_{5}$; and 0, 60 and $120 \mathrm{~kg} \mathrm{~K}_{2} \mathrm{O}$ and their combinations in the form of $25 \%$ calcium ammonium nitrate, $18 \%$ superphosphate, $40 \%$ potassium chloride. The groundwater table was at a depth of 2-3 m below the surface.

Rainfall amounts, deviation in rainfall from the average over many years (dry year: $-10--20 \%$, droughty year: above $-20 \%$; wet year $+10-+20 \%$; year with excess rainfall: above $+20 \%$ ) and other related data were determined based on traditional Hungarian standards (HARNOS, 1993; MÁRTON, 2004) (Tables 1 and 2), and MANOVA (Multivariate Analysis of Variance) by SPSS test (SPSS, 1988). 
Table 2

Frequency of critical months following each other during the vegetation period and in the whole year between 1961-2004 (Long-term fertilization experiment, Örbottyán)

\begin{tabular}{|c|c|c|c|c|c|}
\hline \multirow{4}{*}{ Year } & \multicolumn{2}{|c|}{ Frequency } & & \multicolumn{2}{c|}{ Frequency } \\
\cline { 2 - 3 } & \multicolumn{2}{|c|}{$\begin{array}{c}\text { No. of consecutive critical } \\
\text { months, during the }\end{array}$} & \multirow{2}{*}{ Year } & \multicolumn{2}{c|}{$\begin{array}{c}\text { No. of consecutive critical } \\
\text { months, during the }\end{array}$} \\
\cline { 2 - 3 } & $\begin{array}{c}\text { vegetation } \\
\text { period } \\
\text { (Sept.-July) }\end{array}$ & $\begin{array}{c}\text { whole year } \\
\text { (Oct.-Sept.) }\end{array}$ & & $\begin{array}{c}\text { vegetation } \\
\text { period } \\
\text { (Sept.-July) }\end{array}$ & $\begin{array}{c}\text { whole year } \\
\text { (Oct.-Sept.) }\end{array}$ \\
\hline \multirow{2}{*}{1961} & $2(-3), 2(5)$ & $2(-3), 2(5)$ & 1984 & - & - \\
1962 & $3(9)$ & $3(9), 2(-9)$ & 1985 & - & - \\
1964 & - & - & 1986 & $2(3)$ & $2(3)$ \\
1965 & $2(5), 2(9)$ & $2(5), 3(9)$ & 1987 & $2(-6)$ & $2(-6)$ \\
1966 & - & $2(9)$ & 1988 & $2(-6)$ & $2(-6)$ \\
1967 & $2(6)$ & $2(6)$ & 1989 & $2(-8)$ & $2(-8)$ \\
1968 & - & - & 1990 & - & - \\
1969 & - & - & 1991 & - & - \\
1971 & $2(-8)$ & $2(-8)$ & 1992 & $2(-4)$ & $2(-4), 2(-9)$ \\
1972 & $2(9)$ & $2(9), 2(9)$ & 1993 & $2(-9)$ & $2(-9)$ \\
1973 & - & - & 1994 & - & - \\
1974 & - & - & 1995 & - & - \\
1975 & $2(-9)$ & $2(-9)$ & 1996 & - & - \\
1976 & - & - & 1997 & $2(-6), 2(-9)$ & $2(-6), 2(-9)$ \\
1977 & $2(9), 4(9), 2(2)$ & $2(9), 4(9), 2(2)$ & 1998 & $2(-9), 2(9)$ & $2(-9), 2(9)$ \\
1978 & - & - & 1999 & $2(9)$ & $2(9)$ \\
1979 & $2(6)$ & $2(6)$ & 2000 & $2(-9)$ & $2(-9)$ \\
1980 & $2(3), 2(-2)$ & $2(3), 2(-2), 2(-5)$ & 2001 & $2(-9), 3(9)$ & $2(-9), 3(9)$ \\
1981 & $2(9)$ & $2(9)$ & 2002 & - & - \\
1982 & $2(6)$ & $2(6)$ & 2003 & $2(3)$ & $2(3)$ \\
1983 & $2(-2)$ & $2(-2), 2(-7)$ & 2004 & - & - \\
1961 & $2(-3), 2(5)$ & $2(-3), 2(5)$ & 1984 & - & - \\
\hline & & & & &
\end{tabular}

\section{Results and Discusion}

In average years the yield in the control plots stabilized at around $0.8 \mathrm{t} \cdot \mathrm{ha}^{-1}$ (Table 3). The yield doubled (1.8-1.9 $\left.\mathrm{t}^{-\mathrm{ha}^{-1}}\right)$ in the N, NP and NK treatments, while the full NPK doses gave the maximum yield of $2.1 \mathrm{t}^{\mathrm{h}} \mathrm{ha}^{-1}$.

In dry years yields of $0.7 \mathrm{t} \cdot \mathrm{ha}^{-1}$ were harvested in the control plots. This was a $13 \%$ yield reduction as compared to the many years' mean. Yield depressions of 33 , 16,21 and $20 \%$ were caused by drought in the N, NP, NK and NPK treatments.

In wet years the yield was little more than $0.5 \mathrm{t}^{-\mathrm{ha}^{-1}}\left(0.6 \mathrm{t} \cdot \mathrm{ha}^{-1}\right)$ in the control plots, representing a yield loss of $25 \%$, compared with average years. The N, NP, NK and NPK treatments led to yield depressions of 28, 26, 26 and 26\%. Rye grown in a monoculture has approx. $5 \%$ less tolerance to wet years than to drought. 
Table 3

Effect of mineral fertilization on the yield $\left(\mathrm{t} \cdot \mathrm{ha}^{-1}\right)$ of winter rye (Secale cereale L.) grown in monoculture in average, dry, droughty, wet and very wet years between 1961 and 2004 (Long-term fertilization experiment, calcareous sandy soil, Örbottyán)

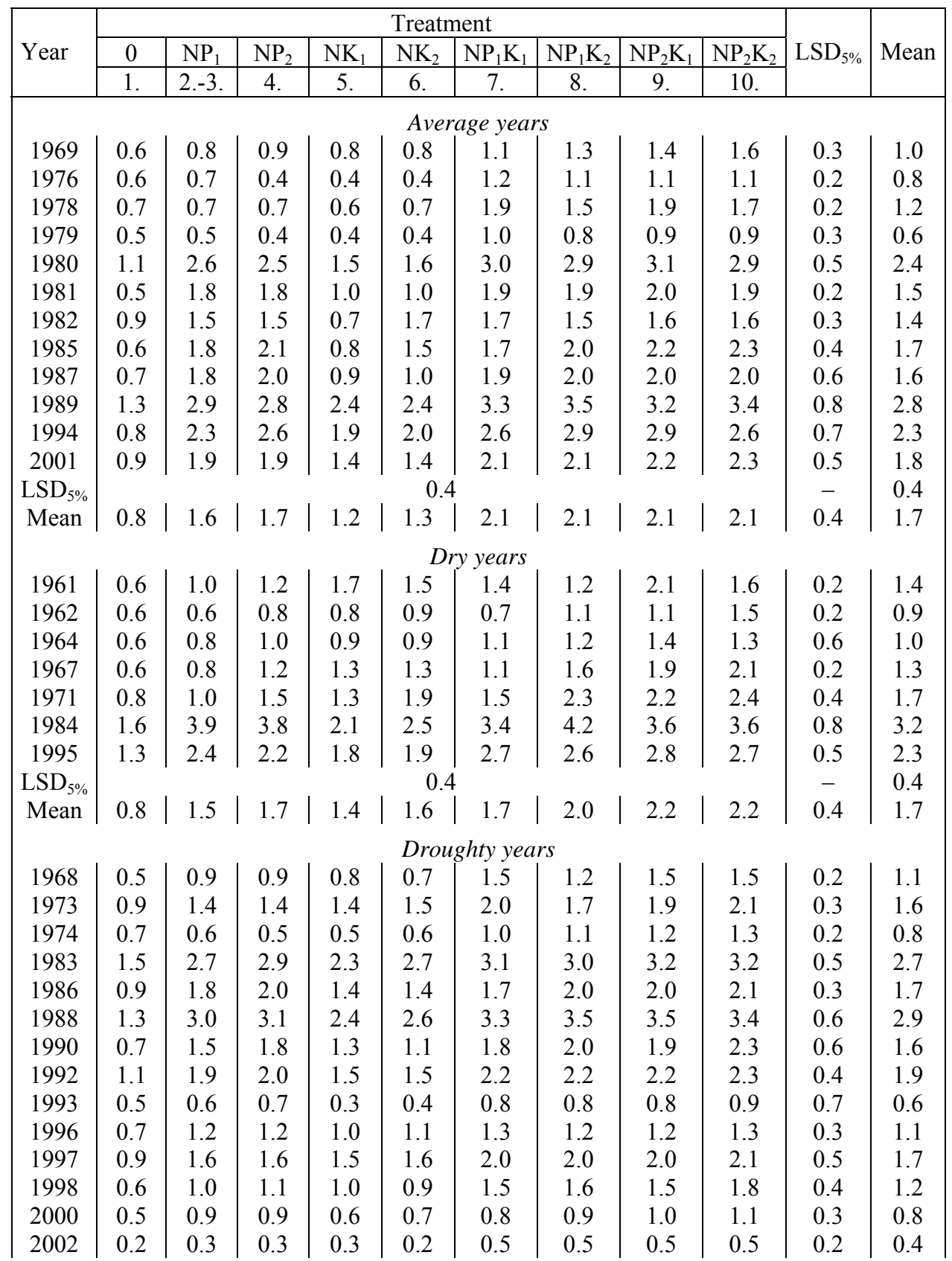


Table 3 cont.

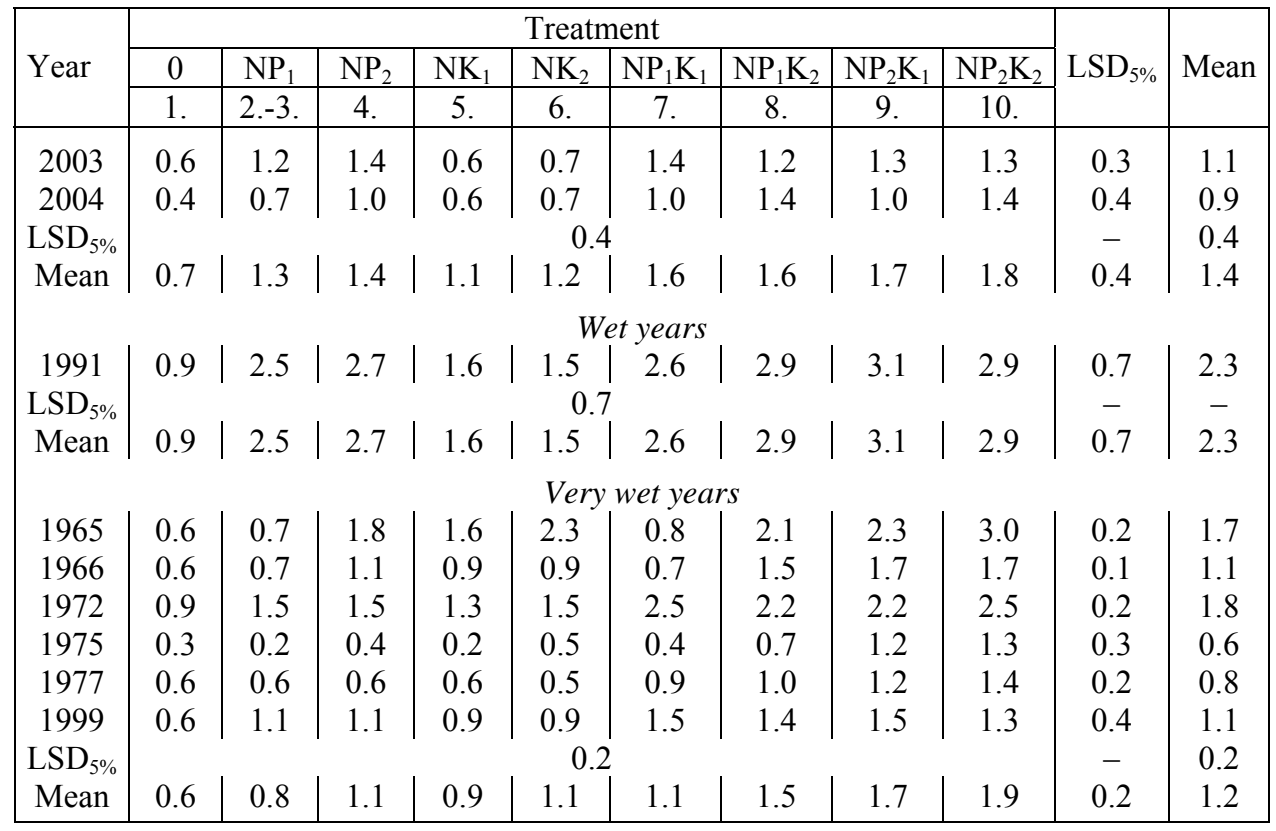

Remarks: Average years: Equivalent to the 30-year (1961-1990) rainfall mean at Örbottyán Experimental Station; dry year: $-10--20 \%$; droughty year: above $-20 \%$; wet year: $+10-$ $+20 \%$; very wet year: above $+20 \%$; For treatments: See Materials and Methods

Depending on the nutrient supplies, significant quadratic correlations were established between rainfall quantity and yield $\left(0: \mathrm{R}=0.7489^{* * *}, \mathrm{~N}: \mathrm{R}=0.8974^{* * *}\right.$, $\mathrm{NP}: \mathrm{R}=0.8020^{* * *}$, $\mathrm{NK}: \mathrm{R}=0.7370^{* * *}$, $\mathrm{NPK}: \mathrm{R}=0.9047^{* * *}$, mean $\mathrm{R}^{2}=0.8180$; $66.9 \%$ ) during the vegetation period.

The increase in grain yield per mm rainfall ranged from 3.0 to $6.4 \mathrm{~kg} \cdot \mathrm{ha}^{-1}$ in the case of optimum rainfall supplies, while the quantity of rainfall during the vegetation period required for the production of $1 \mathrm{~kg}$ air-dry yield ranged between 1529 and 3360 litres in the case of maximum yield.

Based on the meteorological database for the 44 years of the long-term experiment (1961-2004) the frequency of years in which the rainfall was optimum for various levels of nutrient supply was as follows: control: $2 \%, \mathrm{~N}: 7 \%$, NP: $7 \%$, NK: $9 \%$, NPK: $7 \%$, giving an average of $6 \%$ over the treatments. This suggests that the occurrence of optimum rainfall supplies and the possibility of achieving optimum yields in a rye monoculture will decline in the future.

The yield average of rye grown in a monoculture on calcareous sandy soil (Örbottyán) was $86 \%$ less than that achieved in a biculture on acidic sandy soil (Nyírlugos) under similar fertilization and rainfall conditions.

The results show that rye production is totally $(66.9 \%)$ dependent on rainfall and fertilization changes. 


\section{Summary}

The effect of rainfall on crop fertilization factors, such as macronutrients and yield, were studied during a long-term field experiment on a calcareous sandy soil with low humus content in North Hungary at the Örbottyán Experimental Station of RISSAC from 1961 to 2004. At the time of the set-up of the experiment, in 1959, the soil's ploughed layer had the following characteristics: $\mathrm{pH}\left(\mathrm{H}_{2} \mathrm{O}\right)$ : 7.5-7.8, $\mathrm{pH}(\mathrm{KCl}) 6.9-7.1$, humus content: $0.6-1.0 \%$, clay content: $\sim 5 \%, \mathrm{CaCO}_{3}$ content: 3 $7 \%$, AL soluble $\mathrm{P}_{2} \mathrm{O}_{5}$ and $\mathrm{K}_{2} \mathrm{O}$ content: $40-60$ and $50-100 \mathrm{mg} \cdot \mathrm{kg}^{-1}$. The experiment included ten treatments in five replications, giving a total of 50 plots $\left(35 \mathrm{~m}^{2} \mathrm{each}\right)$ arranged in a Latin square design. From the $1^{\text {st }}$ to the $25^{\text {th }}$ year the fertilization rates were 0,50 and $100 \mathrm{~kg} \mathrm{~N} \cdot \mathrm{ha}^{-1} \cdot$ year $^{-1} ; 0$ and $54 \mathrm{~kg} \mathrm{P}_{2} \mathrm{O}_{5} \cdot \mathrm{ha}^{-1} \cdot$ year $^{-1} ; 0$ and $80 \mathrm{~kg}$ $\mathrm{K}_{2} \mathrm{O} \cdot \mathrm{ha}^{-1} \cdot$ year $^{-1}$ and their combinations. From the $26^{\text {th }}$ year on these rates were 0 and $120 \mathrm{~kg} \mathrm{~N} \cdot \mathrm{ha}^{-1} \cdot$ year $^{-1} ; 0,60$ and $120 \mathrm{~kg} \mathrm{P} \mathrm{O}_{5} \cdot \mathrm{ha}^{-1} \cdot \mathrm{year}^{-1}$; and 0,60 and $120 \mathrm{~kg}$ $\mathrm{K}_{2} \mathrm{O} \cdot \mathrm{ha}^{-1} \cdot$ year $^{-1}$ and their combinations. The major findings can be summarized as follows:

In average years the yield in the control plots stabilized at around $0.8 \mathrm{t} \cdot \mathrm{ha}^{-1}$. The yield doubled (1.8-1.9 $\left.\mathrm{t} \cdot \mathrm{ha}^{-1}\right)$ in the N, NP and NK treatments, while the full NPK doses gave the maximum yield of $2.1 \mathrm{t} \cdot \mathrm{ha}^{-1}$. In dry years $0.7 \mathrm{t} \cdot \mathrm{ha}^{-1}$ yields were harvested in the control plots. This meant a $13 \%$ yield reduction as compared to the many years' mean. Yield depressions of 33, 16, 21 and 20\% were caused by drought in the N, NP, NK and NPK treatments. In wet years the yield was little more than $0.5 \mathrm{t} \cdot \mathrm{ha}^{-1}\left(0.6 \mathrm{t} \cdot \mathrm{ha}^{-1}\right)$ in the control plots, representing a yield loss of $25 \%$ in comparison to average years. The N, NP, NK and NPK treatments led to yield depressions of 28, 26, 26 and 26\%. Rye grown in a monoculture has approx. 5\% less tolerance to wet years than to drought. Depending on the nutrient supplies, significant quadratic correlations were observed between the rainfall quantity and the yield (Control: $\mathrm{R}=0.7489 * * *, \mathrm{~N}: \mathrm{R}=0.8974 * * *, \mathrm{NP}: \mathrm{R}=0.8020 * * *$, $\mathrm{NK}$ : $\mathrm{R}=0.7370 * * *$, NPK: $\mathrm{R}=0.9047 * * *$, mean $\mathrm{R}^{2}=0.8180 ; 66.9 \%$ ) during the vegetation period. The increase in grain yield per mm rainfall ranged from 3.0 to $6.4 \mathrm{~kg} \cdot \mathrm{ha}^{-1}$ in the case of optimum rainfall supplies, while the quantity of rainfall during the vegetation period required for the production of $1 \mathrm{~kg}$ air-dry yield ranged from 1529 to 3360 litres in the case of maximum yield. Based on the meteorological database for the 44 years of the long-term experiment (1961-2004) the frequency of years in which the rainfall was optimum for various levels of nutrient supply was as follows: control: $2 \%, \mathrm{~N}: 7 \%$, NP: $7 \%, \mathrm{NK}: 9 \%, \mathrm{NPK}: 7 \%$, giving an average of $6 \%$ over the treatments. This suggests that the occurrence of optimum rainfall supplies and the possibility of achieving optimum yields in a rye monoculture will decline in the future. The yield average of rye grown in a monoculture on calcareous sandy soil (Örbottyán) was $86 \%$ less than that achieved in a biculture on acidic sandy soil (Nyírlugos) under similar fertilization and rainfall conditions. These results show that rye production is totally $(66.9 \%)$ dependent on rainfall and fertilization changes. 
The present study was supported by the Hungarian National Office for Research and the Technology and Hungarian Science and Technology Foundation (Project No.: OMFB-00112/2005-E-2/04 and IND-3/03).

Key words: rye, monoculture, rainfall, fertilization, yield

\section{References}

BARrow, E. M. et al., 2000. Climate change scenarios. In: Climate Change, Climatic Variability and Agriculture in Europe. (Eds.: DownING, T. E. et al.) 28-32. European Commission. Brussels

EM, 2004. International Disaster Database. Washington, D. C.

EU, 2003. Drought Costs EU Farmers Euro of 11 Billion. European Report. Brussels

HARNOS, Zs., 1993. Time sequence analysis of weather and weather-yield relationships. In: Drought 1983. (Eds.: BARÁTH Cs.-NÉ., GYÖRFFY B., HARNOS Zs.) (In Hungarian) 9-46. KÉE. Budapest

JoHnStON, A. E., 2000. Some aspects of nitrogen use efficiency in arable agriculture. K. Scogs-o. Lantbr. Akad. Tidskr.

JOLÁNKAI, M., 2005. Effect of climate change on plant cultivation. (In Hungarian) In: „AGRO-21” Füzetek. 41. 47-58.

KÁDÁR, I., 1992. Principles and Methods in Plant Nutrition. (In Hungarian) MTA TAKI. Budapest

KÁDÁR, I., SZEMES, I. \& LÁSZTITY, B., 1984. Relationship between "year effect" and state of nutrition in a long-term winter rye experiment. Növénytermelés. 33. 235241.

LÁNG, I., 1973. Long-term fertilization experiments on sandy soils. (In Hungarian) Doctor of Sciences Thesis. Hungarian Academy of Sciences. Budapest

LÁNG, I., 2005. Weather and climate change: change-effect-response. (In Hungarian) In: „AGRO-21” Füzetek. 43. 3-10.

LÁNG, I., HARNOS, Zs. \& JOLÁNKAI, M., 2004. Strategies of adaptation to climatic changes: international experiences and possibilities in Hungary. (In Hungarian) In: "AGRO-21" Füzetek. 35. 70-77.

MÁRTON, L., 2002. Climate fluctuations and the effect of $\mathrm{N}$ fertilizer on the yield of rye (Secale cereale L.). (In Hungarian) Növénytermelés. 51. 199-210.

MÁRTON, L., 2003. Effect of mineral fertilization, liming and rainfall on the yield of rye, potato, winter wheat and triticale. (In Hungarian) Agrokémia és Talajtan. 52. 271-290.

MÁRTON, L., 2004. Rainfall and fertilization effects on crops yield in a global climate change. In: Proc. $4^{\text {th }}$ Agroenviron Symposium. Role of Multipurpose Agriculture in Sustaining Global Environment-AGROENVIRON 2004 (Udine, 20-24 Oct., 2004). Part 3. 451-456. DPVTA. Udine

MÁRTON, L., 2005a. Disasters as drought and rainfall excess and artificial fertilization effects on crop yield. In: Proc. Intern. Conf. on Energy, Environment and Disasters-INCEED2005 (Charlotte, 24-30 July, 2005). 49-50. ISEG. Charlotte 
MÁRTON, L., 2005b. Effect of mineral fertilization and rainfall on the yield of maize (Zea mays L.). (In Hungarian) Agrokémia és Talajtan. 54. 309-324.

NÉMETH, T., 2004. Concept of scientific programme of the Research Institute for Soil Science and Agricultural Chemistry of HAS from 2005 to 2010. (In Hungarian) RISSAC. Budapest

NRC (National Research Council), 2002. Abrupt Climate Change. Inevitable Surprises. Committee on Abrupt Climate Change, Ocean Studies Board, Polar Research Board on Atmospheric Sciences and Climate, Division on Earth and Life Studies. National Academy Press. Washington, D.C.

RAJENDRA, K. P., 2004. Foreword. In: Proc. $22^{\text {nd }}$ Session of the Intergovernmental Panel on Climate Change (New Delhi, 9-11 November, 2004). 7-8. IPCC. New Delhi.

Seth, G. P. \& Yeffrey, S. A., 2005. Crops and Environmental Change. Food Product Press. New York-London-Oxford

SPSS Inc., 1988. SPSS/PC+Advanced Statistics TM V2.0. SPSS Inc. Chicago

SzÁSz, G., 2005. Climatic instability causing variability in crop output in the Carpathian Basin. (In Hungarian) In: „AGRO-21” Füzetek. 40. 33-69.

VÁRAllyay, GY., 1992. Effect of global climate change on soil. (In Hungarian) Magyar Tudomány. 9. 1071-1076.

VÁrallyay, Gy., 2005. Possible pedological effects of climate changes in the Kisalföld. (In Hungarian) In: „AGRO-21” Füzetek. 43. 11-23. 